\title{
BRAND IMAGE AND THE FIGHT AGAINST COUNTERFEITING BY THE GUCCI COMPANY
}

\author{
Anastazja Magdalena Kasztalska ${ }^{1}$
}

\begin{abstract}
Gucci is a company that represents a modern approach to the image in the fashion industry. This article aims to answer the question of how taking care of brand imagine results in a higher company income. The research method used in this article is a survey made with the cooperation of buyers of the luxury brand Gucci. Unquestionably, there is a strong link between care for the brand image and fight against counterfeiting. Further research can be focused on an answering the question of how to prevent counterfeiting. Without a doubt, customers prefer brands that have a strong and unique brand image. Counterfeiting unfortunately puts in doubt the value of the brand and is an existing danger for the Gucci company.
\end{abstract}

UDC Classification: 005.3; DOI: http://dx.doi.org/10.12955/cbup.v6.1160

Keywords: Luxury, Brand Image, Gucci, Counterfeit, Marketing, Management.

\section{The Gucci Brand}

Gucci is a luxury Italian brand of clothing and leather goods, it is a part of the Gucci Group, which is owned by the French Luxury group Kering. The Gucci company was founded by Guccio Gucci in Florence in 1921. Currently, the company generates 4.2 billion euro worldwide, it is on the 51st position of the most profitable brands according to the 2017 Interbrand ranking (Interbrand, 2017). Gucci is the best-selling and recognizable Italian brand with 278 directly serviced stores around the world and many warehouses of its products and points of sale of goods in exclusive department stores. In 2017. the brand was valued at 9.969 billion dollars. From January 2015. its creative director and therefore the person responsible for managing the company is Alessandro Michele (Bianchino et al.,1987).

Guccio Gucci, who founded one of the most prestigious brands, producing high-end luxury leather goods, clothing and accessories, was an immigrant working in exclusive hotels in Paris and later in London. Probably the creation of the brand was inspired by luxurious, very precisely made bags and suitcases of guests who arrived at the hotel. Before returning to Florence, where Gucci was from, he undertook an apprenticeship at H.J. Cave and Sons. It is a company that until today is famous for the manual production of very luxurious suitcases and travel bags. After returning to Florence, which in the 1920s abounded in high quality materials and talented craftsmen, Guccio opened his shop, where he sold leather goods in a classic, elegant style. Later, Gucci organized his workshops for industrial production methods, but he always kept traditional aspects of the craft. At first, qualified employees were employed for sewing hand made products from the beginning to the end (all production was done by hand). However, with the development of the company, machines replaced people in the early stages of sewing, only the final design and its finish belonged to craftsmen. Together with his three sons Aldo Gucci, Vasco Gucci and Rodolfo Gucci, Guccio expanded the company, through new stores in Milan and Rome, and additionally in Florence (Arrigo, 2011).

A special, signed pattern of fabric was created, which is used still today, which decorated the material parts of leather bags or shoes. During World War II, due to the lack of materials, the company constructed its products from canvas, which only more spread the characteristic pattern of the patterned fabric. After the Second World War, the Gucci coat of arms, which is a metal shield and an armored, medieval knight surrounded by a ribbon with the name Gucci inscribed on it, became a synonym and symbol of Florence. Gucci also took a lot of inspiration from horse races for example white, green, red straps, which previously were used as a horse girth (DeFanti et al., 2014). Brothers Aldo and Rodolfo Gucci extended the reach of the brand, opening in 1953 in New York the first store in the United States. Throughout the 1950s and 1960s, movie stars, politicians, diplomats and wealthy tourists traveled to Florence to acquire excellent quality leather goods, which proved the craft of Florentine masters of craftsmanship, thus making the Gucci brand an international determinant of the highest social status. World-renowned models began posing for exclusive fashion magazines dressed in clothing and accessories branded by Gucci, which further strengthened and made the company famous all over the world (Steele, 2003).

\footnotetext{
${ }^{1}$ Faculty of Management, Department of Marketing, University of Economics in Katowice, Poland, anastazja.kasztalska@gmail.com
} 
The company prospered throughout the 1970s until the 1980s, when family disputes led the company to the brink of bankruptcy. Son of Rodolfo Maurizio took over the company after his father's death in 1983 and removed his uncle Aldo, who was sent to prison for not paying taxes. Maurizio proved to be an ineffective manager and eventually he had to sell the family business in 1988 to Investcorp, a company based in Bahrain. Maurizio was murdered in Milan in 1995, on behalf of his wife Patrizia Reggiani. Meanwhile, the new investors have promoted America Domenico de Sole, a former helper of the Gucci family, to the position of the head of the branch in the United States in 1994, and later as general director in 1995. Dawn Mello in 1989 as the editor-in-chief, was aware of the company's seriously tarnished reputation, which is why he hired Tom Ford to design the Prêt-à-porter line, and he was subsequently supported to the position of creative director in 1994. Manager Bergdof Goodman also initiated a return to the Florence headquarters instead of Milan. After consultations with Tom Ford, the number of products was reduced from 25,000 to just 5,000. These steps saved the whole enterprise from failing (Forden \& Giannarelli, 2008).

In 1997 there were only 76 Gucci stores and those with license agreements around the world. In 2001, Tom Ford and the designer de Sole were jointly responsible for the most important strategic decisions. The French concern Pinault-Printemps-Redoute (known as Kering), acquired 60\% of Gucci Group in 2003. At that time, de Sole and Tom Ford were announced to leave the company with the expiry of contract. The final collection designed in cooperation with these designers turned out to be a huge commercial success. The company announced the search for their successors in the spring of 2004. This started a competition among the company employees to look for a new team of young and talented designers (Horyn, 2004).

After the departure of key designers, Gucci made to stay three talented constructors who were able to continue the Gucci's success: J. Ray, A. Facchinetti and F. Giannini. They designed previously with the supervision of Tom Ford. Facchinetti was raised to the rank of creative director responsible for the women's collection line in 2004. John Ray worked as a creative director for the men's line of products, but he held this function only for three years. Frida Giannini, who was responsible for designing accessories for both women and men, is now the creative director of the whole brand. In 2006 she was officially announced as the creative director. In 2009 Patrizio di Marco became the general manager of the company. Then Marco Bizzarri on December 12, 2014 was appointed as the CEO, and Frida Giannini replaced Alessandro Michele as creative director, performing his function from January 21, 2015 (Hassan et al., 2016).

\section{The fight with counterfeiting.}

Gucci is one of the most copied and counterfeited brands in the world. In order to make counterfeiting more difficult and at the same time to meet the requirements of increasingly demanding customers, the company has introduced many new materials, e.g. waterproof canvas and satin, used for the production of evening bags (Corley \& Terell, 2013). Exclusive materials like Bamboo was used for the first time to make handbags in 1947 and later it was used for decoration and preventing counterfeit. In 1964 a butterfly pattern was created for new silk scarves and a characteristic accent used today is the crossed, two-fold large $G$ used on buckle straps and other decorative accessories (Levitt \& Schreihans, 2014).

Another way to stop the counterfeit is protecting the company copyrights. Gucci is extremely carefully about its trade marks because it is the part of the company identity. The brand tries to protect its logo as an integrated part of the company. Unfortunately, there exist a lot of counterfeiters that reproduce fake Gucci items. This act destroys the brand. In June 2012. Gucci won trademark dispute against Guess. On October 16, 2013 Gucci won another case for counterfeiting of the trade mark at the US federal county court in Fort Lauderdale, Florida, against several businesses operating on the Internet. November 6, 2013 Gucci once again won the case of trademark dispute and not fair competition against the Guess brand in Nanjing. The Intermediate People's Court of the People's Republic of China, stated that Guess "imitated and copied the Gucci brand collections" (Wang \& Snell, 2013).

\section{Care for the image of the Gucci brand}

The charity activity of the company that builds the prestige of the brand through the company's social awareness is extremely important. Gucci has been an UNICEF partner since 2005, and this has obliged 
the brand to transfer part of the sales revenues of its products to the United Nations Children's Fund. (Moore \& Birtwistle, 2005).

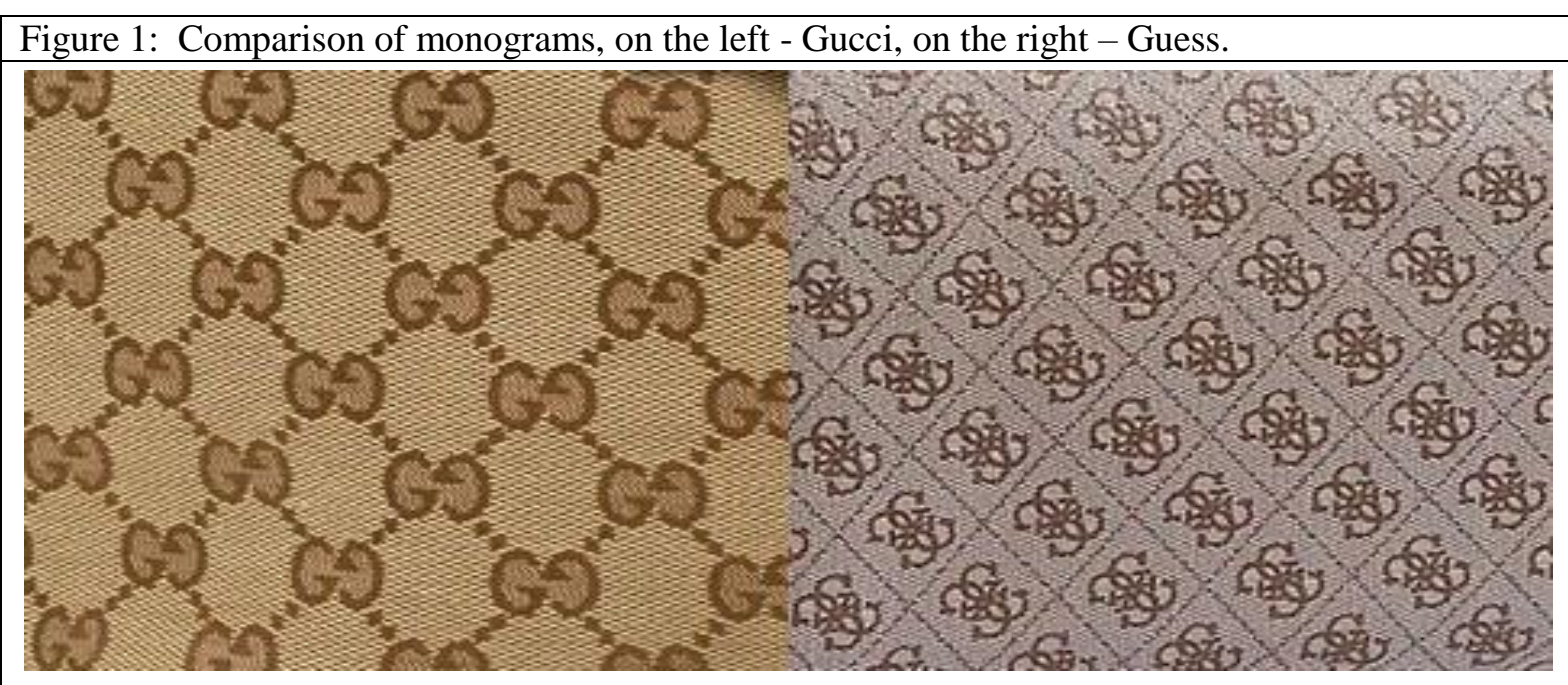

Source: Gucci and Guess official website.

The company is the largest business support for the "School for Africa" program, which aims to increase access to primary school for everyone, with special help for children orphaned as a result of HIV / AIDS and children living in a very bad conditions and extreme poverty. The "Chime for Change" campaign launched in February 2013 works to strengthen the position of women around the world, and the Gucci brand has financed over 210 these projects.

Gucci also organise the charity campaigns combined with the promotion of the brand by well-known people. In 2013, Beyoncé Knowles was announced to collaborate with Salma Hayek and Frida Giannini. Campaigns promoting the event started on February 28, 2013, and the charity concert itself took place on June 1, 2013 in the capital city of England - London. Many artists sang at the concert like Ellie Goulding, Laura Pausini, Florence and the Machine and Rita Ora. Over 130,000 dollars was raised at the concert (Wong \& Dhanesh, 2017).

\section{Methodology.}

The survey omits people that do not have the features such as the knowledge about the luxury market, which are being studied. Respondents to the survey are owners of the items from the luxury brand Gucci or observers/supporters of the brand or the company who have a certain opinion about this market. Individuals who for various reasons are not interested in luxury fashion industry, were excluded from the study because they do not have the relevant interest and a clear opinion about exclusive fashion designers and luxury fashion brands.

The survey was sent by email to people who actively participate in the life of the luxury fashion industry, as well as fans of the Gucci brand around the whole world. In the survey, 160 people participated. The survey was conducted from January 2018 to February 2018. Respondents had a very high degree of freedom of expression because they could modify the questions and add their own observations and comments. Subjects were men and women, diverse in age, as the youngest tested person was 21 years old and the oldest 79. Age and gender had little significance as a major determinant. The main factor was the wealth of a person who can afford to be an owner of luxury items.

The majority of respondents indicated that counterfeiting destroys the image of the brand (86\%), this may be associated with the negative effect that buyers wants to avoid. It appears when someone has original product but because of the popularity of the fake one, the audience thinks that the genuine item is the fake one. A few people decided that counterfeit has a positive influence on the brand (7\%). It can be connected with the bigger recognition of the brand because of the availability of the fake products. Some respondents did not have any opinion about the influence of the counterfeit on the brand (4\%). This could be the result of not being aware of the problem that fake products exist. The smallest group were those who decided that counterfeiting had no influence on the brand (3\%). These 
customers thinks that the Gucci brand has a strong enough position on the market that fake items are not a threat for the brand.

\begin{tabular}{|c|}
\hline Table 1: Results of the survey and data analysis. \\
\hline What do you think about counterfeiting? \\
$\qquad \begin{array}{c}\text { - It destroys the imag } \epsilon \\
\text { brand } \\
\text { It has no influence ol } \\
\text { identity } \\
\text { Counterfeit has posit } \\
\text { influence on the bra } \\
\text { I do not have opinior }\end{array}$ \\
\hline Source: Author based upon data from the survey.
\end{tabular}

Table 2: Results of the survey and data analysis.

\begin{tabular}{|c|c|}
\hline $\begin{array}{c}\text { What is the most important feature for you when } \\
\text { you buy luxury products from the brand Gucci? }\end{array}$ & Answers in \% \\
\hline Branded product & $9 \%$ \\
\hline Value of the brand & $22 \%$ \\
\hline Image of the brand & $44 \%$ \\
\hline Craftsmanship & $12 \%$ \\
\hline History of the brand & $6 \%$ \\
\hline Mission of the brand & $7 \%$ \\
\hline Source: Author based upon data from the survey.
\end{tabular}

The largest number of respondents indicated the brand image (44\%) as the most important factor in their selection of purchasing products from Gucci. Another large group chose the value of the brand (22\%). A much smaller group chosen the craftsmanship (12\%) and branded product (9\%). The least chosen factors by the respondents was the mission of the brand (7\%) and the history of the brand $(6 \%)$.

\section{Conclusion}

Global brands like Gucci are and will be counterfeited. Unfortunately, counterfeiting negatively affects the company that is being counterfeited. Consumers believe that the brand loses a lot of income on such a harmful activity. Small number of customers believe that a strong brand cannot be seriously harmed if it gradually builds its prestige and brand identity. The main conclusion is therefore that the brand must build its prestige through a positive image. Gucci is a strong brand with a very strong position on the market thanks to the care about its own image and fight against the counterfeiting.

\section{References}

Arrigo, E. (2011). Fashion, luxury and design: Store brand management and global cities identity. Symphonya, № (1), 55-67. Bianchino, G., Blanchard, P., \& Evans, C. H. (1987). Italian fashion. The Origins of High Fashion and Knitwear (Vol. 1). Milano: Electa.

Corley, K., \& Terrell, M. (2013). The renaissance of function and its impact on inspired copying: Part II. Intellectual Property \& Technology Law Journal, № 25(12), 17-21,1.

DeFanti, M., Bird, D., \& Caldwell, H. (2014). Gucci's use of a borrowed corporate heritage to establish a global luxury brand. Competition Forum, № 12(2), 45-56. 
Forden, S. G., \& Giannarelli, L. (2008). The house of Gucci: a sensational story of murder, madness, glamour, and greed (Vol. 1). Washington, D.C.: National Library Service for the Blind and Physically Handicapped, Library of Congress, 23.

Horyn, C. (26 $6^{\text {th }}$ February, 2004). "Tom Ford Goes Out with a Roar", The New York Times.

Levitt, C., \& Schreihans, C. (2014). STRATEGY AND LEADERSHIP OF A LUXURY BRAND IN THE POST LOGO

ERA: GUCCI A CASE STUDY. Allied Academies International Conference.Academy of Strategic

Management.Proceedings, № 13(1), 25.

Moore, C. M., \& Birtwistle, G. (2005). The nature of parenting advantage in luxury fashion retailing - the case of gucci group NV. International Journal of Retail \& Distribution Management, № 33(4), 256-270.

Steele, V. (2003) Fashion, Italian Style. New Haven, Connecticut: Yale University Press.

ul Hassan, S. Q., Ilyas, M., \& Rehman, C. A. (2016). CORPORATE BRANDING, EMOTIONAL ATTACHMENT AND BRAND LOYALTY: THE CASE OF LUXURY FASHION BRANDING. Kuwait Chapter of the Arabian Journal of Business and Management Review, № 6(2), 43-57.

Wang, L., \& Snell, R. S. (2013). A case study of ethical issue at gucci in shenzhen, china. Asian Journal of Business Ethics, № 2(2), 173-183.

Wong, J. Y., \& Dhanesh, G. S. (2017). Corporate social responsibility (CSR) for ethical corporate identity management. Corporate Communications, № 22(4), 420-439.

\section{Photos sources:}

1. Official Gucci Webpage Retrieved $5^{\text {th }}$ January 2018 from: www.gucci.com

2. Official Guess Webpage Retrieved $5^{\text {th }}$ January 2018 from: www.guess.com 